\title{
臨床研究
}

\section{外科手術手技の映画づくりにおける腹腔鏡画像 モニターシステムの有用性}

\author{
秋田大学第 1 外科 \\ 田中淳一浅沼義博 小玉雅志 \\ 進 藤 吉 明
}

索引用語 映画, 腹腔鏡, 手術手技

\section{はじめに}

従来, 外科手術手技の実際を供覧する際, 映画 づくりの専門技師による撮影, U-マチック, VHS あるいは $\beta$ ビデオカメラシステムによる撮影が 用いられていた。手術台周囲に固定した三脚や無 影灯にカメラを装着して, 画面のブレ防止ととも に被写体の良視野の確保に細心の注意を必要とし た。しかし，いずれにおいてもカメラは体外にあ ク, 腹腔内あるいは胸腔内の深部の撮影が困難で あることが少なくなかった。一方，最近急速に普 及している腹腔鏡下, あるいは胸腔鏡下手術では, 体腔内にスコープを挿入して術野を良視野にとら え，TVモニター上に高品質の映像を提供してい る。

そこで手術手技の映画づくりに腹腔鏡下手術用 の画像モニタリングシステムを応用し，その有用 性と問題点を検討した。

\section{I 、撮影の実際}

\section{1. ビデオ撮影装置}

腹腔鏡下手術に用いている前方斜視 $30^{\circ}$ の光学 視管(オリンパス社製 A 5255 A), 光源用ライトガ イド(オリンパス社製 A 3092)，TV システムカメ ラ装置（オリンパス社製 OTV-S 4)，高輝度光源 装置 (オリンパス社製 CLV-S)，20 インチカラー モニター(ソニー社製 PVM-2045 MD), Hi 8 ビデ オレコーダー（ソニー社製 EVO-9500 A）を使用
した。

\section{2. 撮影方法}

先ず，上記装置を接続し，ホワイトバランスを とる。術中, 色調節が必要な場合はカメラ装置コ ントロールパネルのマニュアルボタンにより青 色，赤色の度合いを変化させる。スコープは第 3 , あるいは第 4 助手が両手で保持し, 術者の右後方 あるいは対側に位置しながら手術操作の邪魔にな らないようにする。スコープを装着するカメラへ ッドにはズーム，フォーカシングが手元について いるので, 術者の指示にしたがいスコープ保持者 が近接拡大視，あるいは俯瞰視等，モ二タ一画面 をみながら適宜調節する。

\section{3. 手術の撮影}

肝右葉切除術の手術手技を今回の装置を用い て, Video Hi 8 カセットテープ (ソニー社製E 6$120 \mathrm{HME})$ に録画した。すなわち, 肝門部の脈管 処理, 肝下部および肝上部下大静脈のテーピング, 右肝静脈の切離など繊細な処理を必要とする場 面, あるいは携帯カメラでは撮影しにくい場面を, 近接してさらに回転, あるいは角度をつけて撮影 した。

\section{4. 画像の評価}

録画フィルムを再生して，次の点が明らかにな った。すなわち, 本来腹腔内で使用するカメラな ので, 近接した画像は従来のビデオカメラで撮影 したものに比較して色調, 鮮明度, 明暗などにお いて優れている。さらに，スコープは手術野のす 

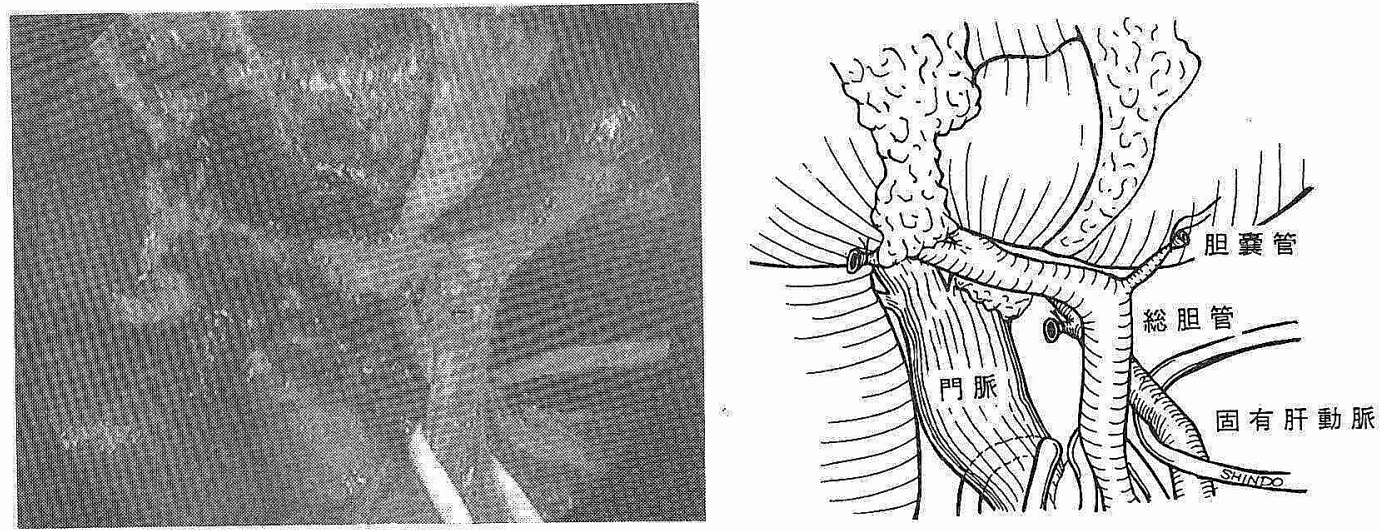

図 1 肝門部の脈管：遊離された門脈，総胆管，固有肝動脈がテーピングされている (右前方からのモ二ター)
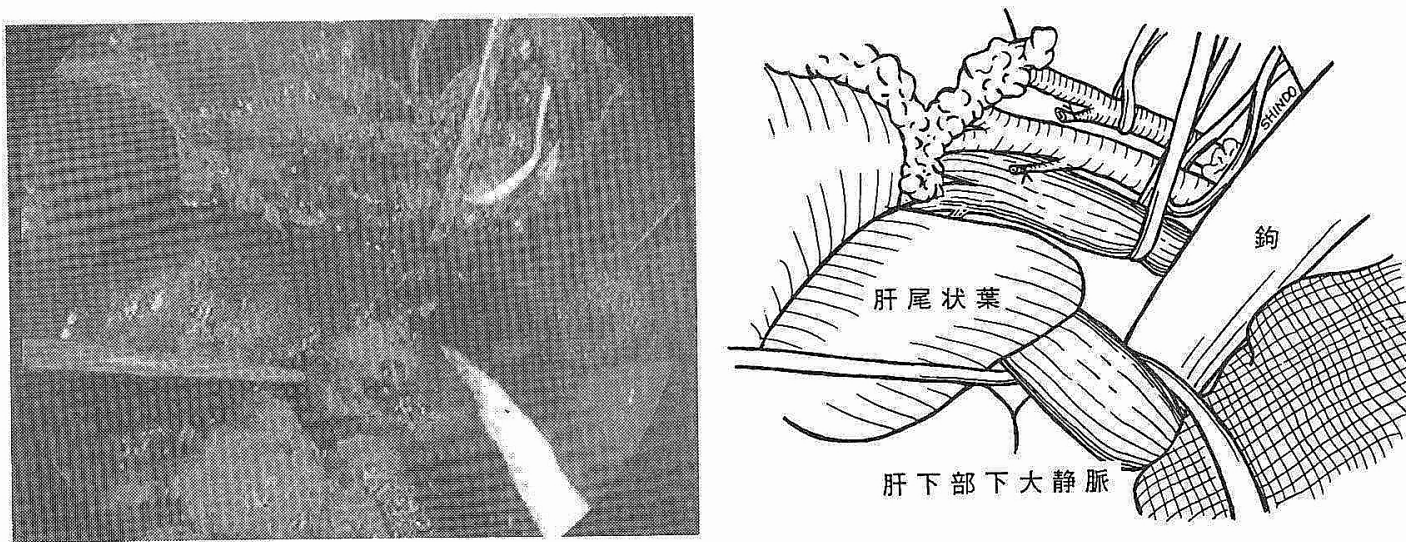

旰下部下大静脈

図 2 肝下部下大静脈：朋十二指腸間膜の後面で肝下部下大静脈にテープがかけられ ている（右側方からのモ二タ一）
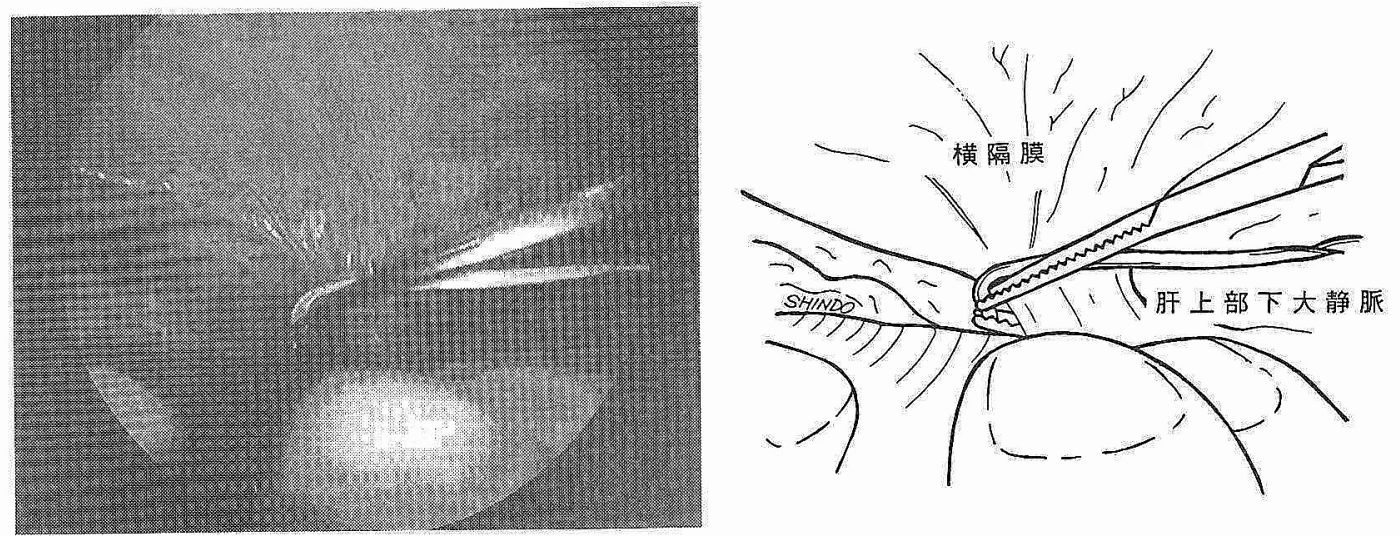

図 3 肝上部下大静脈：肝上部下大静脈へのテーピング（上方からの見下るしもニター） 

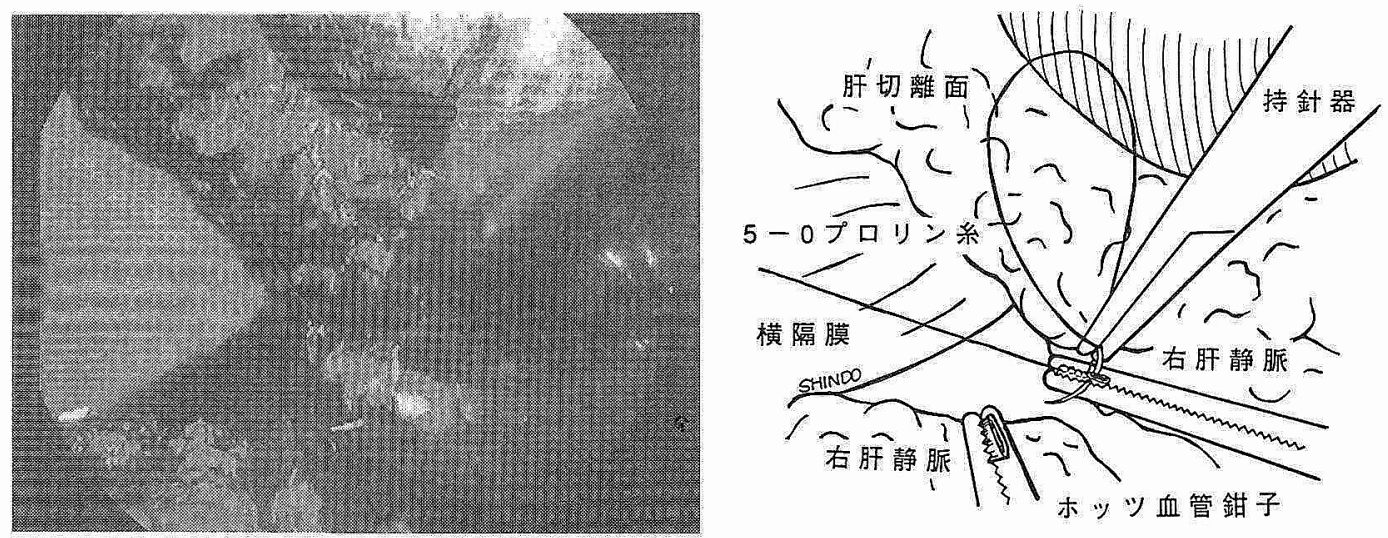

図 4 右肝静脈の切離：右肝静脈に肝内でホッッ血管鉗子をかけ，5-0プロリン糸で 縫合䦥鎖する（右上方加らのも二多一）
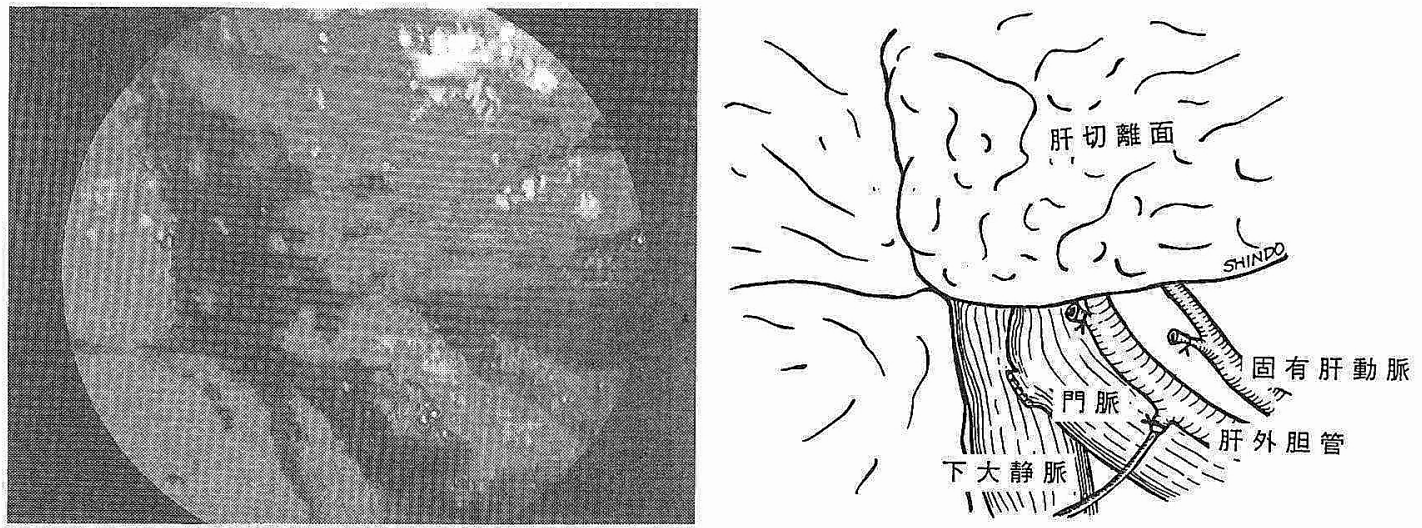

図 5 肝切離面と下大静脈：フィブリン糊で䀒切離面の止血が補強されており，その 背方に下大静脈がみえる（右側方からのモニター）

ぐ近くまで挿入できるので，深部の撮影は容易で ある。しかも，われるれが使用している $30^{\circ}$ 前方斜 視型のスコープは，スコープの回転により，斜め， 横，見おろし，見上げなどのいろいろな力问から の画像が得られるという特徵がある(図 1〜図5)。 これを利用すると左右横隔膜下，骨盤内など，臓 器の側面, 後面がモニタ一され, 近接拡大撮影が 可能である。

\section{II. 考察}

学会, 研究会等でビデオや映画で発表する機会 が増えている。腹腔鏡，胸腔鏡などを用いた内視 鏡下手術住子たんから画像もニターを使用してい るので，ビデオに手術手技を録画することは特別 問題ない。しかし，徒来の開腹下手術あるいは開
胸下手術ではとくに深部の撮影が困難であるとと もに, 術者や助手の頭, 手, 前腕などが, カメ の視野をさえぎることが少なくなく，不便であっ た。

外科手術手技の映画づくりに求められるもの は, 術者の立場，視野にたって術野の展開や手技 のすすめ方を正確に動的映像として記録すること である。従来の遠隔 TVカメラでは, 術者の眼と 被写体を結ぶ線上にカメうをもってくることが不 可能であるため，術者の近傍でなるべく術者の視 野に近くなるような角度での撮影や，術者が頭あ るいは上半身をずらすなどの工夫がなされてい た。

今回われわれが用いた腹腔鏡は外径 $10 \mathrm{~mm} の$ 細長い棒状であり，しかもカメラがその先端につ 
いているので，手術を妨害することなく，適切な 術野を近接して撮影することが可能であった。し かも, スコープの特性上, 深部や狭い空間, 藏器 の側面や後面の撮影が容易であった。しかし，腹 腔鏡モニターシステムを用いることの問題点も明 らかになった。すなわち，遠景俯瞰視では無影灯 の光の影響と, 光源のとどく距離に限界があり, 広い術野の撮影には不適であった。広範囲の撮影 にはむしろ従来の遠隔 TVカメラを用いるべき である。腹腔鏡システムの光源と無影灯からの二 つの光による干涉は画質に影響を与えた。解決方 法として, 近接拡大撮影では無影灯の光量を下げ ることで光の干涉が少なくなり, きれない画像が 撮影できた。この際, カメラの光源そのものが術 野の照明に役立った。

直視型のスコープは今回使用していないが, 構 造上術者の視野を遮る可能性があり，モ二タ一用 には不適切である。 $30^{\circ}$ あるいは $45^{\circ}$ の前方斜視型 のスコープを使用することで術者の視野を遮るこ となく，またスコープ軸の回転により臓器の側面 の撮影が容易にできるという利点がある。

良い視野を得る最も基本的なコツは腹腔鏡医の 技術，腹腔鏡の操作にある。腹腔鏡医はスコープ の取り扱いに習熟していることは言うまでもな く, 手術の内容および映画の目的を理解していな
ければならない。術者もときどきモニタ一画面を チェックする必要がある。また視野を固定して手 術を進める場合は市販のスコープ支持器を利用し てもよい。

画質に関しては, 現在一般に使用されている CCD チップひとつのカメラより 3 CCD チップの カメラでは光の三原色 (RGB) をそれぞれの信号 としてとらえるので, 高品質の映像が得られる。 $3 \mathrm{CCD}$ カメラはいまだ高額であるが, 各種内視鏡 下手術の進歩とともに今後普及してくると考えら れ, 映画づくりへの応用が期待される。腹腔鏡画 像モニターシステムは将来, 三次元 (3-D) 画像モ ニターやコンピューター画像ファイリングシステ $\Delta^{11}$ へと発展していくと考えられ, これらの画像 を利用した映画づくりが可能となるだろう。

\section{おわりに}

われわれが手術手技の映画づくりに活用してい る腹腔鏡画像モニターシステムの有用性と問題点 について述べた。

\section{参考文献}

1）田中淳一, 宮下澄人, 浅沼義博他 : パソコンに よる「画像ファイリング・データベース」の試 作. 外科診療 $36: 481-490,1994$ 